\title{
Landscape features, home-range size and density of northern badgers (Meles meles)
}

\author{
Kaarina Kauhala ${ }^{1}$ \& Katja Holmala²
}

\author{
1) Finnish Game and Fisheries Research Institute, Itäinen Pitkäkatu 3 A, Fl-20520 Turku, Finland \\ (corresponding author's e-mail: kaarina.kauhala@rktl.fi) \\ 2) Finnish Game and Fisheries Research Institute, P.O. Box 4, Viikinkaari 2, Fl-00791 Helsinki, \\ Finland
}

Received 1 Dec. 2010, revised version received 22 Mar. 2011, accepted 9 May 2011

\begin{abstract}
Kauhala, K. \& Holmala, K. 2011: Landscape features, home-range size and density of northern
\end{abstract} badgers (Meles meles). - Ann. Zool. Fennici 48: 221-232.

Knowledge of badger density is important for their conservation especially in areas with low badger densities. Therefore, we aimed to build a simple model to estimate badger density in northern Europe on the basis of habitat characteristics. A radio-tracking study in southern Finland showed that habitat structure of the landscape affects home-range sizes of northern badgers. The data collected from the literature indicate that badger density and home-range size correlate negatively but the relationship was non-linear, with highest densities and smallest home ranges in England. Consequently, badger density can be estimated on the basis of habitat characteristics of the area: density is higher when the proportion of mixed forests is high and that of large spruce forests low and vice versa. Because other factors, such as hunting and predation may be involved, density values should be treated as rough estimates of the density in different landscapes in Finland.

\section{Introduction}

In Finland, the Eurasian badger (Meles meles) occurs close to the northern limit of its distribution range and is virtually absent from the northernmost parts of the country (Kauhala 1995). In a radio-tracking study (Kauhala et al. 2006), badger density was estimated to be low (0.21-0.26 badgers $\mathrm{km}^{-2}$ ) in southeastern Finland. Although badger density is probably also low elsewhere in the country, every year about 10000 badgers are killed by hunters in Finland (Finnish Game and Fisheries Research Institute 2010). Estimates of badger density in different landscapes of the country are essential for con- servation and management purposes, e.g. to prevent too high hunting pressure towards badgers.

Because it is often difficult to count the number of animals directly, many indirect methods, such as remote cameras, track counts, hair collection and scent stations, are used to estimate the density of carnivores (Long et al. 2008). Density of the Eurasian badger can also be estimated by counting the number of their main setts (Thornton 1988, Virgós \& Casanovas 1999, Virgós 2001, Kowalczyk et al. 2003). Counting the number of badger setts to estimate badger density does not, however, work in Finland because badgers in this country often use many small dens, which they change frequently 
(Kauhala et al. 2006). Large main setts are less common in Finland. Multiple use of setts has also been reported in other areas with low badger density, e.g. by Revilla et al. (2001) in Spain, Kowalczyk et al. (2004) in Poland and Loureiro et al. (2007) in Portugal.

Badger density tends to correlate negatively with home-range size: in areas, such as England where badger home ranges are small, population density is usually high and vice versa (e.g. Rogers et al. 1997, Kauhala 2002, Kowalczyk et al. 2003, Rosalino et al. 2004, Kauhala et al. 2006). Home-range size, in turn, is often influenced by the abundance of food or other resources and is thus connected to habitat quality (e.g. Boutin 1984, 1990, Hulbert et al. 1996, Okarma et al. 1998, Feore \& Montgomery 1999, Kowalczyk et al. 2003, Prange et al. 2004, Palphramand et al. 2007). Because habitat quality affects home-range size and home-range size and density tend to correlate, badger density is affected, at least partly, by habitat quality (Kruuk \& Parish 1982, Thornton 1988, Reason et al. 1993, Macdonald et al. 1996, Virgós \& Casanovas 1999, Virgos 2001, Jepsen et al. 2005). By determining how habitat characteristics influence home-range size and how home-range size and density are connected we can estimate badger density on the basis of habitat characteristics in different landscapes. Knowledge of the connection between habitat quality and badger density is important for their conservation and management especially in areas with low badger densities, such as northern Europe. Badger density should be taken into account in land use plans, such as silvicultural measures to increase biodiversity of the country.

The first aim of the present study was to reveal, by using radio tracking, landscape features affecting home-range size of badgers near the northern border of their range (Finland). We assumed that home ranges are smallest where mixed and pine forests dominate, fields are common and spruce forests are scarce, according to the habitat preferences of badgers determined from radio-tracking studies in southern Finland (Holmala \& Kauhala 2009, Kauhala \& Auttila 2010). Secondly, we aimed to determine the connection between home-range size and badger density using the data collected from the litera- ture across Europe. Finally, we aimed to build a model illustrating the relationship between habitat characteristics and badger density to be able to estimate badger density on the basis of habitat characteristics in different landscapes.

\section{Material and methods}

\section{Study areas}

We selected three study areas in different landscapes of southern Finland (Fig. 1): Ruissalo island near the city of Turku, SW Finland $\left(60^{\circ} 26^{\prime} \mathrm{N}, 22^{\circ} 10^{\prime} \mathrm{E}\right)$, Tuulos in the province of Häme, south-central Finland $\left(61^{\circ} 10^{\prime} \mathrm{N}, 2^{\circ} 50^{\prime} \mathrm{E}\right)$ and Virolahti in the province of Kymi, SE Finland $\left(60^{\circ} 32^{\prime} \mathrm{N}, 27^{\circ} 41^{\prime} \mathrm{E}\right)$. Study areas were defined as the outer convex polygons including all location fixes of radio-tracked badgers. The surface area was $7.3 \mathrm{~km}^{2}$ in Ruissalo, $43.7 \mathrm{~km}^{2}$ in Tuulos and $59.7 \mathrm{~km}^{2}$ in Virolahti. Ruissalo is an island and a 'periurban' area in the extreme southwestern tip of Finland where the climate is mildest and marine (mean annual temperature $=6.2{ }^{\circ} \mathrm{C}$ ). Tuulos and Virolahti are rural, partly agricultural areas with fields and farmhouses, and partly commercial coniferous forests. In Virolahti in particular, the landscape is heterogeneous with small deciduous forests and fields in the south and poorer coniferous forests in the north. In Virolahti, the climate is more continental with warm summers but cold winters (mean annual temperature $=4.2{ }^{\circ} \mathrm{C}$ ). The climate in Tuulos is intermediate (mean annual temperature $=5^{\circ} \mathrm{C}$ ). Human density in all areas is low: in Ruissalo, there are some old villas with large gardens, mainly used as summer houses, and in the other areas there are small villages with scattered farmhouses and summer cottages.

\section{Habitat types}

We identified 12 habitat types in the home ranges: gardens, fields (both fields of grain and hayfields), pastures, deciduous forests, mixed forests, spruce forests, pine forests, meadows, open woodland, rock, bogs and reed beds. This classification was based on the CORINE data- 
base (CORINE land cover data 2000, ${ }^{\circ}$ EEA). Meadows and open woodlands are open biotopes on mineral soil with tree canopy cover of $<10 \%$ and $10 \%-30 \%$, respectively. Meadows in particular have dense and tall undergrowth. In Tuulos and Virolahti, meadows also included clear cuts, and open woodlands included sapling stands.

In forests, tree canopy cover is $>30 \%$. Spruce forests consist of $>75 \%$ coniferous trees, mainly Picea abies, growing on mineral soil. The undergrowth in these forests consists of e.g. of bilberries (Vaccinium myrtillus) and May lilies (Maianthemum bifolium) due to the rich mineral soil. Pine forests consist of $>75 \%$ coniferous trees, mainly Pinus sylvestris, on rocky soil. Pine forests are very barren, the undergrowth being mainly lichens. Deciduous forests consists of $>70 \%$ deciduous trees on mineral soil, mainly birches Betula pendula and B. pubescens, alders Alnus incana and A. glauca, willows Salix spp., aspen Populus tremula and rowan Sorbus aucuparia in Tuulos and Virolahti. Deciduous forests in Ruissalo are old and dominated by oak Quercus robur, lime Tilia cordata and European hazel Corylus avellana, but there are also woods with e.g. Betula spp., Populus tremula and Sorbus aucuparia. Mixed forests are rich forests on mineral soil where the proportions of both coniferous and deciduous trees are $<70 \%$. The forests in Tuulos and Virolahti are commercial forests, whereas large areas of Ruissalo are protected and the forests are only slightly managed mature forests.

\section{Radio tracking}

Home ranges of badgers were estimated using VHF radio telemetry. The badgers were captured with wired box-traps, anaesthetized by an intramuscular injection of ketamine hydrochloride and fitted with radio collars (weight ca. $100 \mathrm{~g}$, model TW-3, 138-138.5 MHz, Biotrack, Dorset, UK). Only animals of adult size were fitted with radio-collars.

Radio tracking was done from a car with a three-element Yagi antenna. Bearings were taken from at least two points usually within five minutes, the angle between the bearings being as close to $90^{\circ}$ as possible.

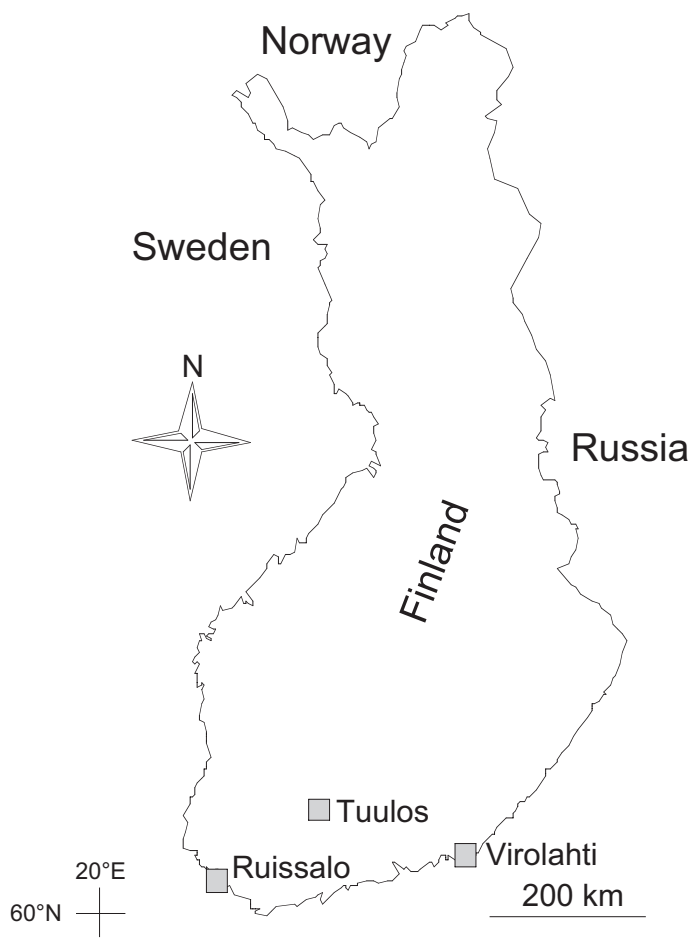

Fig. 1. Study areas in southern Finland.

Badgers were radio tracked in summer (MayAugust), because in Finland badgers hibernate from October until March or April, depending on weather conditions and snow cover. Data were collected between 2001 and 2003 in Virolahti and between 2006 and 2008 in Ruissalo and Tuulos. During some nights the animals were located once every 15 minutes between 19:00 and 06:00, but we also located them now and then during other times. The mean number of tracking nights per animal was $18(\mathrm{SD}=8.4)$.

\section{Data}

Data were collected for 25 badger home ranges (10 males and 15 females; 6 in Ruissalo, 11 in Tuulos and 8 in Virolahti). We used only individual home ranges in the analyses, because most badgers seemed to be solitary. It is, however, possible that not all badgers were trapped, because badgers in Finland are fairly 'trap shy'.

The number of locations varied greatly in Virolahti and was sometimes much larger than in the other areas. Therefore, we excluded 
every second or third location (depending on the number of locations) in some cases from the data of Virolahti. This was done because it is possible that the number of location fixes affects the estimates of home-range size. After this procedure, the number of locations per home range was fairly stable, $72 \pm 12.7 \mathrm{SD}$, in all study areas and did not correlate with home-range size ( $p=$ 0.392). We thus aimed to have approximately the same number of locations per home range in each area to ensure that the number of locations would not affect the estimated home-range sizes. However, we also compared the home-range sizes in Virolahti calculated from all locations with those calculated using the reduced number of locations and found that the home ranges were almost equal (mean 950 ha with reduced $n$ and mean 990 ha with all locations). In all further analyses concerning Virolahti we thus used home ranges calculated from the reduced number of locations. The final number of locations used was 1812 .

Although successive locations of an animal may be auto-correlated, they can be used in home range calculations if there are several trackingnights per home range (Smith et al. 1981) and the time interval between successive locations is relatively constant (de Solla et al. 1999). Our data fulfilled these criteria. Eliminating data due to autocorrelation reduces the biological relevance of kernel home range estimates.

\section{Home range calculations}

We calculated badger home ranges using the fixed kernel method (Worton 1989), applying the reference smoothing parameter (1.0). We used the software RANGES 6, Anatrack Ltd. (Kenward et al. 2003). Kernel 95\% home ranges (K95) were considered the area the animal uses during normal activities (Worton 1989). Using 95\% kernel home range excludes the most severe outliers, such as location errors and hazardous trips by the animals outside their normal home range.

\section{Habitat analysis}

We imported the home ranges from Ranges 6 to ArcView $3.2\left(\mathrm{ESRI}^{\circledR}\right)$. Home ranges were inter- sected from a digital habitat map to calculate habitat compositions of the home ranges (K95), i.e. the percentages of each habitat type described above. We also calculated habitat patchiness (number of habitat patches per ha) and the mean sizes of different habitat patches for each home range. Habitat patchiness and patch sizes were obtained from Patch Analyst 3.1 for ArcView 3.2. The map (CORINE land cover data 2000, ${ }^{\circ}$ EEA) for Finland was produced by the Finnish Environment Institute ( ${ }^{\circledR} \mathrm{SYKE}$; www.environment.fi). The digital maps were vectorised from a raster map and the resolution was $25 \times 25 \mathrm{~m}$.

\section{Statistical analyses}

The normality of distributions was tested using the Kolmogorov-Smirnov one-sample test. We used General linear models (GLM) to determine whether study area or sex affected home-range size. We used classical discriminant analysis with the percentages of the different habitat types and habitat patchiness as predictors to test whether habitat structure of the home ranges differed between the study areas. We thus wanted to include all habitat types into a single test to evaluate how well the analysis could classify the home ranges correctly to the three study areas on the basis of their habitat compositions. We then used an ANOVA to determine which habitat types differed between the study areas.

We built a model (GLM, model 1) to show the impact of habitat characteristics on individual home-range size (stepwise analysis, backward procedure, variables with $p<0.05$ included in the model). The dependent variable was the size of K95. We selected the set of independent variables used in the final test from a correlation matrix. The independent variables tested were the percentages of the main habitat types, the mean sizes of habitat patches and habitat patchiness. The independent variables in the final test, chosen from the correlation matrix, were the proportions of habitat types, the sizes of spruce forest, mixed forest and field patches and habitat patchiness. Because the proportions of spruce forests and bogs correlated strongly ( $r=0.79$, $p<0.001$ ), we added bogs to the spruce forests variable. 


\section{Literature review}

We collected data on badger home-range sizes and density from 23 papers from different countries across Europe to determine the connection between home-range size and density. We assumed the relationship between home-range size and badger density to be correlative but to describe the relationship between them we performed a linear regression model (model 2) to be able to substitute home-range size with density in model 1 (above). The final model (model 3) thus gives the relationship between badger density and habitat variables. We also calculated correlations between latitude and home-range size and badger density. Because we know that badger densities in England are much higher than in most other areas (e.g. Johnson et al. 2002), 'latitude' used here was the absolute value of latitude, calculated as the true latitude of each study area - the latitude of southern England $\left(52^{\circ} \mathrm{N}\right)$, because we aimed to see how home-range size and density change when distance from England increases either to the south or north.

\section{Results}

\section{Home-range sizes}

Mean home range (K95) size differed significantly between the study areas, home ranges being smallest in Ruissalo and largest in Virolahti (means \pm SD: Ruissalo $134 \pm 53.0$ ha, $n$ = 6; Tuulos $306 \pm 111.7$ ha, $n=11$; Virolahti $949 \pm 444.6$ ha, $n=8$ ). Home-range sizes of males and females were not significantly different (Table 1). Therefore, the data for both sexes were pooled in the subsequent analyses.

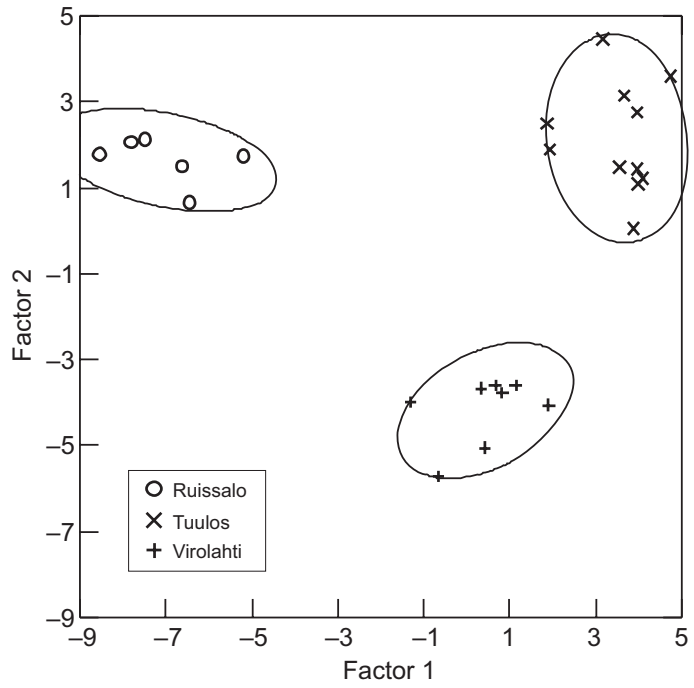

Fig. 2. Result of the classical discriminant analysis. Percentages of different habitat types and habitat patchiness were the predictors and study area was the grouping variable.

\section{Habitat analyses and model 1}

Habitat compositions of the home ranges differed between the study areas, as shown by classical discriminant analysis (Fig. 2), which classified home ranges correctly into the study areas on the basis of habitat characteristics of the home ranges (classification $100 \%$ correct, Jackknifed classification $92 \%$ correct, Wilk's $\lambda=0.005, F_{18,28}=21.3$, $p<0.001$; Fig. 2). Deciduous forests, open woodlands, rocks and reed beds were more common in the home ranges in Ruissalo than in the other study areas (Fig. 3). Mixed forests were most common in the home ranges in Tuulos whereas spruce forests and bogs were most common in the home ranges in Virolahti. Habitat patchiness was greater in Ruissalo (2.8 patches per ha) than in Tuulos (1.6) and Virolahti (1.5; $p<0.001)$.

Table 1. Results of the general linear model (GLM) with kernel 95\% home range (K95) of badgers as the dependent variable and study area and sex as the independent variables. $r^{2}=0.65, n=25$.

\begin{tabular}{lrrrrr}
\hline Source & Type III SS & df & Mean squares & $F$ & $p$ \\
\hline Study area & 2440476 & 2 & 1220238 & 16.8 & $<0.001$ \\
Sex & 1493 & 1 & 1493 & 0.02 & 0.887 \\
Error & 1520996 & 21 & 72428 & & \\
\hline
\end{tabular}




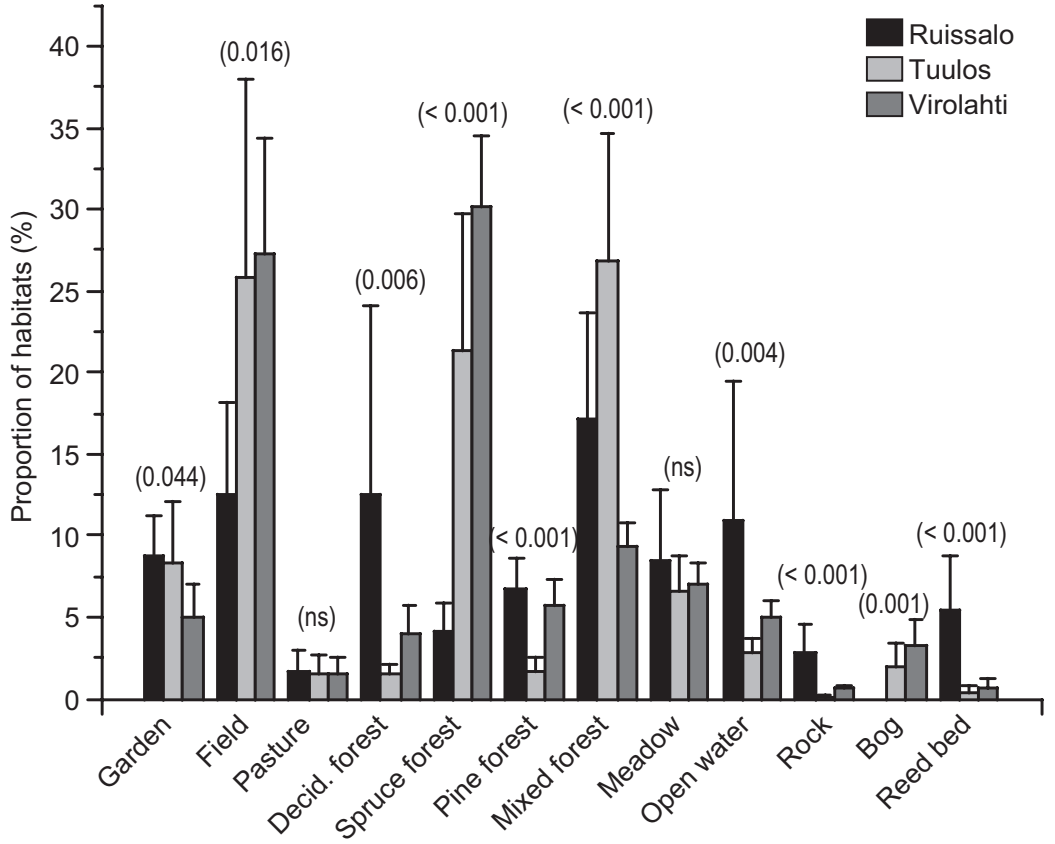

Fig. 3. Proportions of different habitat types in home ranges (fixed kernel $95 \%, \mathrm{~K} 95)$ of the badgers in the three study areas in southern Finland. Means $+\mathrm{SD}$ are given; $p$ values (ANOVA) for differences between the study areas per habitat type are in parentheses above the columns.
Since there were only three study areas (landscapes) and there was individual variation in home-range sizes within the study areas (each of which in fact consisted of different subareas, e.g. forested and agricultural areas), we pooled the data from all the areas to determine the habitat features influencing individual home-range sizes. GLM indicated that home ranges were small when the percentage of mixed forest was high and that of spruce forest low and vice versa (Table 2). The model explained $60 \%$ of the variation in home-range size. Model 1 was:

Home range $(\mathrm{ha})=$

$348-18.2 \times$ percentage of mixed forest

$+21.1 \times$ percentage of spruce forest.

\section{Models 2 and 3}

The literature indicated a negative correlation between $\log$ (home-range size) and $\log$ (badger density) ( $r=-0.84, n=35, p<0.001$; Fig. 4A). The relationship between home-range size and badger density was, however, not linear (Fig. 4B). There was large variation across Europe and badgers in England seemed to differ from the rest of Europe. In England, badger density increases with increasing group size even when territory size does not change (e.g. Kruuk \& Parish 1982). Therefore, we calculated the final model (model 2) excluding data from England. Again there was a good fit between $\log$ (homerange size) and $\log$ (badger density) $(r=-0.78, n$ $=24, p<0.001)$. Model 2 was:

Table 2. Results of the general linear model (GLM) when the effects of habitat variables on kernel $95 \%$ home range size (K95) of badgers were tested. $r^{2}=0.60, F_{2,22}=16.6, n=25, p<0.001$.

\begin{tabular}{lrrrrrr}
\hline Effect & Coefficient & SE & $\begin{array}{c}\text { Standard } \\
\text { coefficient }\end{array}$ & Tolerance & $t$ & $p$ \\
\hline Constant & 348.1 & 157.7 & 0 & 2.21 & 0.038 & 0.005 \\
Mixed forest & -18.2 & 5.8 & -0.42 & 1.0 & -3.13 & $<.79$ \\
Spruce forest & 21.1 & 4.4 & 0.65 & 1.0 & $<0.001$ \\
\hline
\end{tabular}


Fig. 4. Relationships between home-range size and badger density based on a literature review. Literature used: England: Cheeseman et al. 1981, Kruuk \& Parish 1982, Packham 1983, Cresswell \& Harris 1988, Rogers et al. 1997, Johnson et al. 2002, Palphramand et al. 2007; Finland: Kauhala et al. 2006, Kauhala \& Auttila 2010; Germany: Hoffmann 1999 after Kowalczyk et al. 2003; Ireland: Feore and Montgomery 1999; Italy: Pigozzi 1987 after Johnson et al. 2002; Luxemburg: Frantz et al. 2010; Norway: Bevanger et al. 1996; Poland: Kowalczyk et al. 2003; Portugal: Rosalino et al. 2004, Scotland: Kruuk \& Parish 1982, 1987: Spain: Martin \& Delibes 1985 according to Johnson et al. 2002, Rodriquez et al. 1996, Revilla et al. 2000, Revilla \& Palomares 2002, Molina-Vacas et al. 2009; Switzerland: Graf et al. 1996 according to Johnson, Do Linh San et al. 2007.
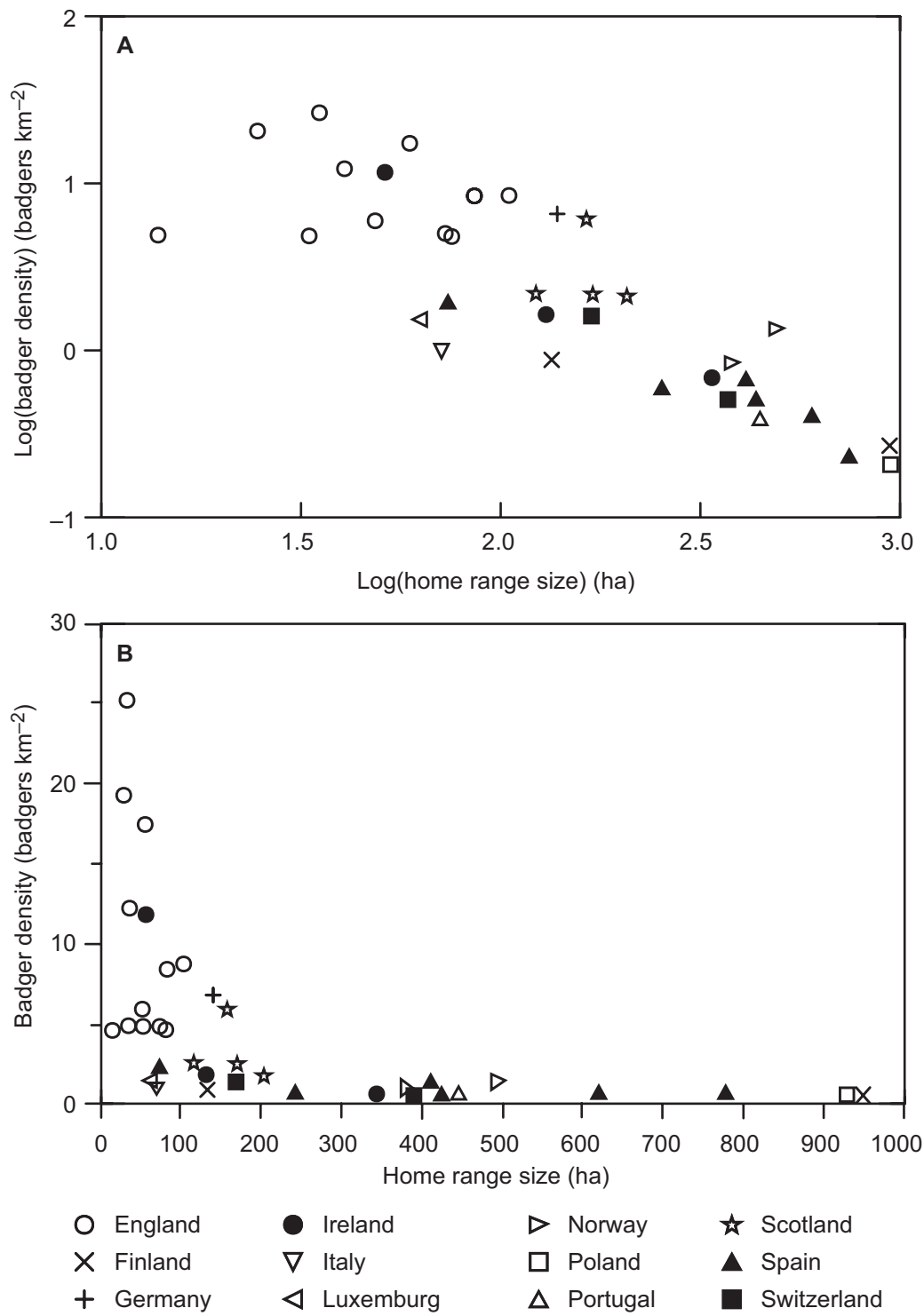

$\log \left(\right.$ badger density) $\left(\right.$ badgers $\left.\mathrm{km}^{-2}\right)=$ $a+b \times \log$ (home-range size) (ha),

where $a=2.28$ and $b=-0.95$.

We furthermore calculated the model by excluding both England and the Mediterranean region to obtain a model which would better illustrate the situation in central and northern Europe. This model was also significant $(r=$ $-0.73, n=9, p=0.025)$. In this model $a=1.97$ and $b=-0.82$.

By combining models 1 and 2, badger density can be estimated on the basis of habitat char- acteristics of the landscape (model 3):

Log (badger density) (badgers $\left.\mathrm{km}^{-2}\right)=a+b$ $\times \log (348-18.2 \times$ percentage of mixed forest $+21.1 \times$ percentage of spruce forest),

where the $a$ and $b$ values are the same as for model 2.

There was also a positive correlation between latitude (true latitude $-52^{\circ} \mathrm{N}$ ) and home-range size $(r=0.58, p<0.001)$ and a negative correlation between latitude and badger density $(r=$ $-0.60, p<0.001)$. 


\section{Discussion}

\section{Habitat characteristics affecting home- range size}

Home-range sizes of individual badgers differed between the study areas. Home ranges were small when the proportion of mixed forest was high and that of spruce forest low (model 1). Our prediction thus came partly true. Patchiness was also one of the variables tested, but did not increase the coefficient of determination $\left(r^{2}\right)$ of the model significantly, because patchiness and the percentage of spruce forest correlated negatively $(r=-0.72, p<0.001)$. Consequently, only one of them could be included in the model. The negative correlation between patchiness and the percentage of spruce forests indicates that spruce forests usually occur in large patches. This kind of environment is not ideal for badgers.

Home ranges were smallest in Ruissalo where mature mixed and deciduous forests covered one third of the home ranges and patch size was small and spruce forests were sparse. Because of mineral soil and sparse undergrowth in the mixed and deciduous forests of Ruissalo it may be easy for badgers to dig earthworms (Lumbricus terrestris). Other studies have also shown the connection between good quality habitat and small home-range size. In the Białowieża Primeval Forest (Poland), in Norway and in Scotland, home-range size was influenced by the distribution of deciduous forests rich in earthworms (Kruuk 1978a, Kruuk \& Parish 1982, Kruuk 1989, Brøseth et al. 1997, Kowalczyk et al. 2003). In southern England, badger territories were small (50-150 ha) in an area with earthworm-rich deciduous and mixed forests and farmland (Kruuk 1978b). Furthermore, variation in rainfall correlated negatively with territory size in Britain because temperature and moisture affect earthworm abundance (Evans \& Guild 1947, Woodroffe \& Macdonald 1993). In Northern Ireland, badger-group territories were smallest where mixed woodland was common (Feore \& Montgomery 1999). In Denmark, badger home ranges were large in an area where the earthworm biomass was low (Elmeros et al. 2005).

Home ranges were largest in Virolahti where mixed forests were scarce but large commercial spruce forests covered almost one third of the home ranges. In the coniferous forests of Virolahti, badgers are omnivorous and require vast home ranges to fulfill their energy needs (Kauhala et al. 1998). Also in Belarus, in an area characterized by a low biomass and uneven distribution of earthworms, badgers were generalist predators (Sidorovich et al. 2011). In the Białowieża Primeval Forest, where almost half of the study area consisted of coniferous forests, individual badger home ranges were almost equal to those in Virolahti (mean 930 ha; Kowalczyk et al. 2003). Home ranges were also large in Spain in areas dominated by dry scrubland, marshland and pinewood habitats where badgers prey mainly on rabbits (Oryctolagus cuniculus; Rodriques et al. 1996, Revilla \& Palomares 2002).

Other factors besides habitat, e.g. sex, age and body mass of badgers may also affect their homerange size (Kowalczyk et al. 2003). Home-range size did not vary with sex in the present study or in a coniferous habitat in northeast England (Palphramand et al. 2007). The effect of age on home-range size could not be tested in the present study, because we did not know the age of the radio-tracked badgers. Furthermore, the distribution of badger setts can determine the size of badger territories (Doncaster \& Woodroffe 1993, Roper 1993) but this is unlikely in areas such as northern Europe, where badger density is low and badgers use many different dens (Brøseth et al. 1997, Kowalczyk et al. 2004).

\section{Habitat, home-range size and badger density}

We found a negative relationship between homerange size and density of badgers (model 2). Other studies have also shown that badger density tends to correlate negatively with homerange size (e.g. Feore \& Montgomery 1999, Kauhala 2002, Molina-Vacas et al. 2009). Consequently, because habitat characteristics affect home-range size, we can expect that they also influence badger density: in northern Europe density is expected to be highest in areas which constitute of a small-scale mosaic of habitat patches and where mixed forests are common but large spruce forests and bogs are scarce (model 3). The 
relationship between habitat and density has also been observed in many other studies (e.g. Thornton 1988, Reason et al. 1993, Seiler et al. 1995, Macdonald et al. 1996, Virgós \& Casanovas 1999, Kowalczyk et al. 2000, Virgos 2001). Furthermore, Kowalczyk et al. (2003) found a correlation between habitat (oak-lime-hazel forest) and home-range size and between earthworm abundance and badger density across Europe. The latter correlation was also shown by Kruuk (1989) in Scotland. Because earthworm abundance depends on habitat, especially soil type, it can be concluded that habitat affects both homerange size and badger density. It is thus possible to estimate badger density from the habitat characteristics of the landscape. It is, however, evident that our model does not accurately provide absolute densities but it can be used, for instance, to compare badger density/relative abundance in different landscapes for management or conservation purposes.

The relationship between home-range size and badger density was not linear (Fig. 4B). Home ranges were smallest ( $<100$ ha) and density highest (up to 25 badgers $\mathrm{km}^{-2}$ ) in England where food, mainly earthworms, is abundant. When badger density was $>12$ badgers $\mathrm{km}^{-2}$, the mean territory size did not decrease any further with increasing density $(p=0.680)$. In these areas the distribution of suitable den sites may determine the smallest territory size and highest density of badger social groups (Woodroffe \& Macdonald 1993, also reviewed by Kowalczyk et al. 2003). A further increase in badger density may occur with an increase in group size only in good quality habitats, rich in a rapidly renewable food source, e.g. earthworms, and therefore badgers in England live in large clans when food is abundant (Kruuk 1978a, Kruuk \& Parish 1982, Woodroffe \& Macdonald 1993, Kowalczyk et al. 2000).

With distance from England, either to the north or south, home-range size increased and density decreased. Woodroffe and Macdonald (1993) also found a positive correlation between latitude and territory size in data from the Mediterranean region and Britain. At lowest densities (0.21-0.8 badgers $\mathrm{km}^{-2}$ ), mean home-range size varied between 242 and 949 ha. However, in Belarus the mean size of group territories was
2550 ha in one summer (Sidorovich et al. 2011). Most of the low-density areas were either in the dry forests or shrublands of the Mediterranean region (e.g. Molina-Vacas et al. 2009) or in central and northern Europe where winters are harsh (e.g. Kowalczyk et al. 2003, Kauhala et al. 2006; Fig. 4). Furthermore, Johnson et al. (2002) found an association between climate, especially seasonality, and badger densities. In low-density areas badger density is limited by food abundance and badgers are often solitary or live in pairs (Ahnlund 1980, Revilla \& Palomares 2002, Kowalczyk et al. 2003). Earthworm abundance, which is influenced by habitat type and climate (Woodroffe \& Macdonald 1993, Kowalczyk et al. 2003), thus affects not only home-range size and density, but also the social system of badgers.

The greatest increase in density (from 2.112.3 badgers $\mathrm{km}^{-2}$ ) occurred when mean homerange size decreased from 206 ha to 41 ha. These areas were in central and western Europe (Germany, England, Scotland and Ireland).

Besides habitat, latitude and the social system of badgers, other factors may influence badger density. One of these is hunting, which is common in Finland. Badgers are caught with traps or hunted with earth dogs, the hunting bag being about 10000 each year (Finnish Game and Fisheries Research Institute 2010). Furthermore, badgers commonly fall victim to traffic in southern Finland (pers. obs.). Also Molina-Vacas et al. (2009) suggested that sett disturbance, poaching and road kills may affect badger density. Additionally, predation may influence badger density, or avoidance of predation may influence badger behaviour and thus their movements and homerange sizes (Sidorovich et al. 2011). Predation by large carnivores, such as lynx (Lynx lynx) may indeed affect badger density in Finland, since the lynx population has increased rapidly in the country during the last decade (Heikkinen \& Kojola 2010). Sidorovich et al. (2011) calculated that wolves (Canis lupus) and lynxes can exterminate half of the local badger population in Belarus. Bevanger and Lindström (1995) also suggested that killing of large carnivores increased the number of badgers in northern Europe.

Badger density in Finland is naturally low, mainly due to a poor environment but also possibly due to predation. Furthermore, the reproduc- 
tive rate of badgers is low. Under these circumstances hunting may have an impact on badger population densities, especially in areas where badgers occur close to the northern border of its distribution. These factors should be taken into account in game management.

\section{Conclusions}

The home-range size of northern badgers is affected by habitat structure of the landscape and because home-range size and density tend to correlate, we can estimate badger density on the basis of habitat characteristics of the landscape. Because other factors, such as hunting, predation and road kills may be involved, density values should be treated as rough estimates of density in different landscapes in northern Europe.

Knowledge of the relative density of badgers in different landscapes and the factors influencing it is needed for badger population management and conservation. Badgers could also be an indicator species in northern areas: where the relative density of badgers is high, other species, for example roe deer (Capreolus capreolus), wildboar (Sus scrofa) and many birds living in rich mixed forests may also thrive. Taking these factors into consideration in silvicultural measures (e.g. by favouring mixed forests instead of large spruce forests) the biodiversity of northern areas could be enhanced.

\section{Acknowledgements}

We wish to thank two anonymous referees for valuable comments on the manuscript and P. Jounela for statistical advice. We are very grateful to M. Auttila, R. Kumpulainen, W. Lammers, T. Metsälä, J. Rainio, J. Schregel, L. Seikola and other field assistants for radio tracking the badgers. Local hunters helped us in capturing the badgers. S. Heikkinen constructed the digital habitat maps. The city of Turku, the Ministry of Agriculture and Forestry, the Science foundation of Helsinki University and the Finnish Cultural foundation provided financial support for the project.

\section{References}

Ahnlund, H. 1980: Sexual maturity and breeding season of the badger, Meles meles in Sweden. - Journal of Zool- ogy 190: 77-95.

Bevanger, K. \& Lindström, E. R. 1995: Distributional history of the European badger Meles meles in Scandinavia during the 20th century. - Annales Zoologici Fennici 32: 5-9.

Boutin, S. 1984: Effect of late winter food addition on numbers and movements of snowshoe hares. - Oecologia 62: 393-400.

Boutin, S. 1990: Food supplementation experiments with terrestrial vertebrates: patterns, problems, and the future. - Canadian Journal of Zoology 68: 203-220.

Brøseth, H., Knutsen, B. \& Bevanger, K. 1997: Spatial organization and habitat utilization of badgers Meles meles: effects of food patch dispersion in the boreal forest of central Norway. - Zeitschrift für Säugetierkunde 62: 17-22.

Cheeseman, C. L., Jones, G. W., Gallagher, J. \& Mallinson, P. J. 1981: The population structure, density and prevalence of tuberculosis (Myobacterium bovis) in badgers (Meles meles) from four areas in south-west England. Journal of Applied Ecology 18: 795-804.

de Solla, S. R., Bonduriansky, R. \& Brooks, R. J. 1999: Eliminating autocorrelation reduces biological relevance of home range estimates. - Journal of Animal Ecology 68: 221-234.

Do Linh San, E., Ferrari, N. \& Weber, J. M. 2007: Socio-spatial organization of Eurasian badgers (Meles meles) in a low-density population of central Europe. - Canadian Journal of Zoology 85: 973-984.

Doncaster, C. P. \& Woodroffe, R. 1993: Den site can determine shape and size of badger territories: implications for group-living. - Oikos 66: 88-93.

Elmeros, M., Madsen, A. B. \& Prang, A. 2005: Home range of the badger (Meles meles) in a heterogenous landscape in Denmark. - Lutra 48: 35-44.

Evans, A. C. \& Guild, W. J. McL. 1947: Studies on the relationships between earthworms and soil fertility. I. Biological studies in the field. - Annals of Applied Biology 34: 307-330.

Finnish Game and Fisheries Research Institute 2010: Hunting 2009. - Riista- ja kalatalous - Tilastoja 6/2010. Official Statistics of Finland - Agriculture, Forestry and Fishery.

Feore, S. \& Montgomery, W. I. 1999: Habitat effects on the spatial ecology of the European badger (Meles meles). - Journal of Zoology 247: 537-549.

Heikkinen, S. \& Kojola, I. 2010: Numbers and reproduction of large carnivores in 2009. - In: Wikman, M. (ed.), Riistakannat 2010: Riistaseurantojen tulokset. Riista- ja kalatalous - Selvityksiä 21/2010: 31-33 [In Finnish with English abstract].

Hofmann, T. 1999: Untersuchungen zur Ökologie des europäischen Dachses (Meles meles, L. 1758) im Hakelwald (nordöstliches Harzvorland). - Ph.D. thesis, Martin Luther University, Halle-Wittenberg, Germany.

Holmala, K. \& Kauhala, K. 2009: Habitat use of mediumsized carnivores in southest Finland - key habitats for rabies spread? - Annales Zoologici Fennici 46: 233-246.

Hulbert, I. A., Iason, G. R., Elston, D. A. \& Racey, P. A. 
1996: Home range sizes in a stratified upland landscape of two lagomorphs with different feeding strategies. Journal of Applied Ecology 33: 1479-1488.

Jepsen, J. U., Madsen, A. B., Karlsson, M. \& Groth, D. 2005: Predicting distribution and density of European badger (Meles meles) setts in Denmark. - Biodiversity and Conservation 14: 3235-3253.

Johnson, D. D. P., Jetz, W. \& Macdonald, D. W. 2002: Environmental correlates of badger social spacing across Europe. - Journal of Biogeography 29: 411-425.

Kauhala, K. 1995: Changes in the distribution of the European badger Meles meles in Finland during the rapid colonization of the raccoon dog. - Annales Zoologici Fennici 32: 183-191.

Kauhala, K. 2002: European badger - a social mustelid? - Suomen Riista 48: 7-17 [In Finnish with English summary].

Kauhala, K. \& Auttila, M. 2010: Habitat preferences of the native badger and the invasive raccoon dog in southern Finland. - Acta Theriologica 55: 231-240.

Kauhala, K., Holmala, K., Lammers, W. \& Schregel, J. 2006: Home ranges and densities of medium-sized carnivores in south-east Finland, with special reference to rabies spread. - Acta Theriologica 51: 1-13.

Kauhala, K., Laukkanen, P. \& von Rége, I. 1998: Summer food composition and food niche overlap of the raccoon dog, red fox and badger in Finland. - Ecogaphy 21: $457-463$.

Kenward, R. E., South, A. B. \& Walls, S. S. 2003: Ranges6 v1.2: For the analysis of tracking and location data. Anatrack Ltd., Wareham, UK.

Kowalczyk, R., Bunevich, A. N. \& Jędrzejewska, B. 2000: Badger density and distribution of setts in Białowieża Primeval Forest (Poland and Belarus) compared to other Eurasian populations. - Acta Theriologica 45: 395-408.

Kowalczyk, R., Zalewski, A., Jędrzejewska, B. \& Jędrzejewski, W. 2003: Spatial organization and demography of badgers (Meles meles) in Białowieża Primeval Forest, Poland, and the influence of earthworms on badger densities in Europe. - Canadian Journal of Zoology 81: 74-87.

Kowalczyk, R., Zalewski, A. \& Jędrzejewska, B. 2004: Seasonal and spatial pattern of shelter use by badgers Meles meles in Białowieża Primeval Forest (Poland). - Acta Theriologica 49: 75-92.

Kruuk, H. 1978a: Foraging and spatial organization of the European badger, Meles meles L. - Behavioral Ecology and Sociobiology 4: 75-89.

Kruuk, H. 1978b: Spatial organization and territorial behaviour of the European badger Meles meles. - Journal of Zoology 184: 1-19.

Kruuk, H. 1989: The social badger. - Oxford University Press, Oxford.

Kruuk, H. \& Parish, T. 1982: Factors affecting population density, group size and territory size of the European badger, Meles meles. - Journal of Zoology 196: 31-39.

Kruuk, H. \& Parish, T. 1987: Changes in the size of groups and ranges of the European badger (Meles meles L.) in an area in Scotland. - Journal of Animal Ecology 56: 351-364.
Long, R. A., MacKay, P., Zielinski, W. J. \& Ray, J. C. (eds.) 2008: Noninvasive survey methods for Carnivores. Island Press, Washington.

Loureiro, F., Rosalino, L. M., Macdonald, D. W. \& SantosReis, M. 2007: Use of multiple den sites by Eurasian badgers, Meles meles, in a Mediterranean habitat. Zoological Science 24: 978-985.

Macdonald, D. W., Mitchelmore, F. \& Bacon, P. J. 1996: Predicting badger sett numbers: evaluating methods in East Sussex. - Journal of Biogeography 23: 649-655.

Molina-Vacas, G., Bonet-Arbolí, V., Rafart-Plaza, E. \& Rodríguez-Teijeiro, J. D. 2009: Spatial ecology of the European badgers (Meles meles) in Mediterranean habitats of the north-eastern Iberian Peninsula. I: Home range size, spatial distribution and social organization. - Vie et Milieu - Life and Environment 59: 223-232.

Okarma, H., Jędrzejewski, W., Schmidt, K., Śnieżko, S., Bunevich, A. N. \& Jędrzejewska, B. 1998: Home ranges of wolves in Białowieża Primeval Forest, Poland, compared with other Eurasian populations. - Journal of Mammalogy 79: 842-852.

Palphramand, K. L., Newton-Cross, G. \& White, P. L. 2007 : Spatial organization and behaviour of badgers (Meles meles) in a moderate-density population. - Behavioral Ecology and Sociobiology 61: 401-413.

Pigozzi, G. 1987: Behavioural ecology of the European badger (Meles meles L.): diet, food availability and use of space in Maremma Natural Park, central Italy. Ph.D. thesis, University of Aberdeen, Aberdeen.

Prange, S., Gehrt, S. D. \& Wiggers, E. P. 2004: Influences of anthropogenic resources on raccoon (Procyon lotor) movements and spatial distribution. - Journal of Mammalogy 85: 483-490.

Reason, P., Harris, S. \& Cresswell, P. 1993: Estimating the impact of past persecution and habitat changes on the numbers of Badgers Meles meles in Britain. - Mammal Review 23: 1-15.

Revilla, E., Palomares, F. \& Delibes, M. 2000: Defining key habitats for low density populations of Eurasian badgers in Mediterranean environments. - Biological Conservation 95: 269-277.

Revilla, E., Palomares, F. \& Fernández, N. 2001: Characteristics, location and selection of diurnal resting dens by Eurasian badgers (Meles meles) in a low density area. Journal of Zoology 255: 291-299.

Revilla, E. \& Palomares, F. 2002: Spatial organization, group living and ecological correlates in low-density populations of Eurasian badgers, Meles meles. - Journal of Animal Ecology 71: 497-512.

Rodriques, A., Martín, R. \& Delibes, M. 1996: Space use and activity in a Mediterranean population of badgers Meles meles. - Acta Theriologica 41: 59-72.

Rogers, T., Cheeseman, C. L. \& Mallinson, P. J. 1997: The demography of a high-density badger (Meles meles) population in the west of England. - Journal of Zoology 242: 705-728.

Roper, T. J. 1993: Badger setts as a limiting resource. - In: Hayden, T. J. (ed.), The badger: 24-34. Royal Irish Academy, Dublin.

Rosalino, L. M., Macdonald, D. W. \& Santos-Reis, M. 2004: 
Spatial structure and land-cover use in a low-density Mediterranean population of Eurasian badgers. - Canadian Journal of Zoology 82: 1493-1502.

Seiler, A., Lindström, E. \& Stenström, D. 1995: Badger abundance and activity in relation to fragmentation of foraging biotopes. - Annales Zoologici Fennici 32: 37-45.

Sidorovich, V. E., Rotenko, I. I. \& Krasko, D. A. 2011: Badger Meles meles spatial structure and diet in an area of low earthworm biomass and high predation risk. Annales Zoologici Fennici 48: 1-16.

Smith, G. J., Cary, J. R. \& Rongstad, O. J. 1981: Sampling strategies for radio-tracking coyotes. - Wildlife Society Bulletin 9: 88-93.

Thornton, P. S. 1988: Density and distribution of Badgers in south-west England - a predictive model. - Mammal
Review 18: 11-23.

Virgós, E. 2001: Role of isolation and habitat quality in shaping species abundance: a test with badgers (Meles meles L.) in a gradient of forest fragmentation. - Journal of Biogeography 28: 381-389.

Virgós, E. \& Casanovas, J. G. 1999: Environmental constrains at the edge of a species distribution, the Eurasian badger (Meles meles L.): biogeographical approach. Journal of Biogeography 26: 559-564.

Woodroffe, R. \& Macdonald, D. W. 1993: Badger sociality - models of spatial grouping. - Symposium of the Zoological Society of London 65: 145-169.

Worton, B. J. 1989: Kernel methods for estimating the utilization distribution in home-range studies. - Ecology 70: $164-168$. 